\title{
CITRUS (RUTACEAE): A REVIEW OF RECENT ADVANCES IN ETYMOLOGY, SYSTEMATICS AND MEDICAL APPLICATIONS ${ }^{1}$
}

\author{
D.J. MABBERLEY \\ Nationaal Herbarium Nederland, Universiteit Leiden branch, P.O. Box 9514, 2300 RA Leiden, \\ The Netherlands; National Herbarium of New South Wales, Royal Botanic Gardens Sydney, \\ Mrs Macquaries Road, Sydney NSW 2000, Australia
}

\section{SUMMARY}

The naming, introduction and classification of citrus crops and their allies is outlined. Traditional medicinal use and 'Western' applications in the treatment of scurvy and obesity, the prevention of AIDS, and in contraception is reviewed. Names for the commercially significant citrangequat (Citrus $\times$ georgiana $)$ and the 'sunrise lime' or 'faustrimedin' $(C . \times$ oliveri $)$ are provided.

Key words: Citrus, Rutaceae, AIDS, citrangequat, contraception, etymology, obesity, sunrise lime, vitamin C.

\section{INTRODUCTION}

To enter on the citrus fruits is to lose insight. I listened to a principal and reliable citizen who in his garden had 26 kinds of them

Gaspar Escolano 1610 (quoted by García Guijarro, 1957)

Orange-blossom and eau de Cologne, Curacao and Cointreau, Earl Grey tea and marmalade, orangeries and pomanders, Nell Gwynn and sun-tan oil, citrus is certainly more than orange-juice. But citrus-growing is the most important fruit industry in warm countries and contributes significantly to the economies of Australia, the United States (California, Florida), Brazil, South Africa, Israel and southern Europe (notably Spain and Portugal). At the same time, in Asia, citrus fruits have been used in local and commercial medicinal preparations for hundreds of years (Imbesi \& De Pasquale, 2002: 589 et seqq.). Moreover, the readily transported and easily stored fruits have entered the folklore and medicinal practice, as well as the cuisine, of countries way beyond.

\section{ETYMOLOGY}

\section{Cedrus to citrus?}

Oranges and lemons have been referred to the genus Citrus L. (Rutaceae) since the time of Linnaeus, who combined Tournefort's Aurantium (orange), Citreum (citron) and Limon (lemon) under a classical name first applied to the coniferous tree Tetraclinis

1) Modified from a paper presented at 'Plants in Health and Culture' Symposium, Leiden, February 2004. 
articulata (Vahl) Mast. (citron tree), known to the Ancient Greeks as thyon and to the Romans as citrus (Meiggs, 1982: 286-291). It was highly valued for its sweet-scented timber (citrum), used for table-tops in antiquity.

According to the 'Oxford English Dictionary', it is possible that this word is cognate with the Greek kedros, from which the Latin cedrus and English cedar have been derived. In classical Latin, cedrus was applied to species of Juniperus, and later applied to other conifers, but today's scientific usage is restricted to the genus Cedrus, including the Cedars of Lebanon (C. libani A. Rich.). However, in common names, cedar is used for trees whose timbers have similar qualities and these include not only conifers but also members of the mahogany family, Meliaceae (Mabberley, 2004), notably species of Cedrela (West Indian cedar) and Toona (red cedar [of Australia]).

The citrum was used to scent clothes and rooms and, in classical Latin, anything smelling of this Tetraclinis wood was 'citrosus' (Glare, 1982: 329). No true Citrus was known to Europeans until Alexander the Great reached Persia and India and saw Citrus medica L., now used in the Jewish Feast of the Tabernacles ('Etrog') in the place of 'persea' (probably Mimusops laurifolius (Forssk.) Friis (Sapotaceae; Manniche, 1989: 121). About 327 BC Alexander took it to the Mediterranean and it is was to be figured in Roman frescoes in Pompeii and at El-Jem in North Africa. Pollen remains at Pompeii and near Naples confirm that citrus was being grown there, and not merely figured, in Roman times (Lippi, 2000). It would also appear that from the Latin word came the Greek kitron. By the eighth century a form of $C$. medica ('Fingered'), with finger-like processes and resembling a berry affected by bud mites, was introduced to China (Needham, 1986: 370), where it is still used to scent rooms and flavour sweets and tea (Valder, 1999: 254). In the West it is sold by florists as 'Buddha's Hand'.

The first-known citrus fruit to reach Europe, then, was not eaten and it seems not unreasonable to argue that it got its common name because of its scenting qualities, in the same way as did the timbers for their qualities discussed above. Thus the new fruit became citreum and later, confusingly, citrus - and what in English is called the citron, which is otherwise nothing to do with the classical citron (Tetraclinis articulata). The English word is also confusing, even today, because in French citron is the lemon (citroen in Dutch), Citrus $\times$ limon (L.) Osbeck (but see below).

\section{Nārandj to Golden Apples and Oranges}

Before Linnaeus's time, citrus fruits had come to be known in Europe as aurantiae (= gold) in Latin (Ramón-Laca, 2003). According to the 'Oxford English Dictionary', post-classical Latin has pomum arantiae (1297) leading to Italian pomerancia and German Pomeranze, from which variants have become stabilized as surnames. The name aurantiae was used by Nicolás Monardes who published it in his 'De citriis, aurantiis, ac limoniis' in Seville in 1540 (Fernández \& Ramón-Laca, 2002), apparently uncertain whether the use of the name in Greece was from the fruits' golden colour or the city of Arantia [=?]. It has been suggested, then, that from the French or (gold) comes orenge in Old French (see below), but the Arabic word is närandj, and this comes from Persian nārang and Sanskrit nāranga which seems to be a much more plausible origin. From the Arabic comes both Spanish naranja (late fourteenth century) and Portuguese laranja (1377). The word is said to have come ultimately from another language, perhaps from a Dravidic or Tamil root (as nraga) meaning fragrant (Ramón-Laca, 2003). 
The term orange was transferred to a colour because of the colour of the fruit's pericarp and there are many place-names involving it. In New South Wales, Australia, there is the town of Orange. It was named in the early nineteenth century by Major Thomas Mitchell (1792-1855), the surveyor, but unlike, e.g., Orange County in California, this has nothing to do with citrus: in fact the town is renowned for its apples! The name commemorates the Prince of Orange with whom Mitchell had been associated in the Peninsular War and who was later to become King Willem II of Holland. Although the colour orange was officially adopted by Willem's ancestor William the Silent, Prince of Orange, as early as 1572, this seems to have been a pun, this time on the name of his town of Orange in France, which place apparently has no connexion with either the colour or the fruit (the town was anciently Arausio, and, in Old French, Orenge).

\section{Golden Apples and Hesperides}

The tough-coated berry of citrus is referred to in botany as an hesperidium, an allusion to the mythological Golden Apples of the Hesperides, said to be beyond the Atlas Mountains of North Africa (Hammond \& Scullard, 1970). The Hesperides sisters (variously three, four or seven) included Aegle and Hesperethusa, commemorated today in generic names, the first for the bael fruit (Aegle marmelos (L.) Corrêa) sacred to Hindus, the second now a synonym of Naringi Adans. (probably derived from an Indian rendering of nāranga), both referring to citrus allies. In his 'natural orders', Linnaeus used the term Hesperidae for the group we would now call Rutaceae tribe Aurantieae (syn. Citreae). But, sadly, the Golden Apples of the Hesperides seem really to have been quinces (Cydonia oblonga Mill., Rosaceae).

\section{Etymological summary}

It would therefore appear that the names of both citrus and orange are surrounded by a series of confusions, false etymologies and perhaps puns. From the Classical Latin for a scented coniferous timber has perhaps come the name of the citron and all other citrus fruits. From the Sanskrit vernacular name (also with roots referring to its scent) has come the name for the orange, which has also become the name of a colour. Independently, the French town name with no such connexions has apparently been punned by the forebears of the Dutch Royal House, such that their heraldic colour is ultimately hi-jacked from Sanskrit. In Renaissance Europe further confusion was engendered by the naming of the Aurantiae for citrus and then came more confusion with the Apples of the Hesperides (quinces), this muddle preserved today in the technical term hesperidium (now used for the wrong fruit; Jackson, 1900: 121), a term coined by the French botanist Augustin Desvaux (1784-1856).

\section{INTRODUCTION TO 'THE WEST'}

Only long after the introduction of the citron did oranges and lemons, limes, mandarins and kumquats, leech-limes and others appear in Europe from further east in Asia. Lemons, limes, pomelos and sour oranges were introduced by the Muslims via the Iberian Peninsula and Sicily, sweet orange and mandarin came only much later, between the fifteenth and nineteenth centuries, through trade with Portugal's and Britain's Asian colonies (Ramón-Laca, 2003). 
The important parts of the citrus plant in commerce are the flowers and the hesperidia. The sweetly scented flowers so redolent of the Riviera and long associated with the Virgin Mary, thence a sign of virginity when worn by the bride at her wedding (Goody, 1993: 167, 175, 241, 244), are the source of neroli oil used in eau de Cologne and many 'bisexual' scents (e.g. CK One by Calvin Klein) worn by humans. Honey from orange flowers (azahar in Spanish, from Arabic az-zahr, meaning flowers in general) with almonds are the ingredients of true Spanish nougat, while azahar water is used in the preparation of a ring-shaped cake (roscón de Reyes) eaten at Epiphany in Spain (Ramón-Laca, in litt., May 2004).

Of greater interest to us here is the hesperidium. What we have in effect is a tough but non-shattering sphere containing carpels (segments) each containing hairs (vesicles) pumped up with juice and bathing the seeds. All parts are of commercial significance. The fruit wall contains the 'zest' of the kitchen and is full of insecticidal materials typical of Rutaceae and their allies, many of them of significant medicinal value (Bisignano \& Saija, 2002). The vesicles provide the juice of commerce and this also has a number of medicinal qualities now coming to the fore once more. The seeds themselves are the source of another oil - petitgrain oil, again used in perfumery. Neither the enormous fresh fruit and juicing industry on the one hand, nor perfumery on the other, will be considered further here. We will concentrate on the botany, ethnobotany and finally the medicinal applications.

\section{THE GENUS CITRUS}

Fossils (Fisher \& Butzmann, 1998) referred to the genus Citrophyllum are known from the Cretaceous and the Eocene of North America and possibly the Oligocene of the Caucasus. Others referred to the genus Citrus are known from the Palaeocene/Eocene of China and Pliocene of Italy, while Hesperidophyllum of the Italian Eocene may be congeneric. Citroxylon wood is known from the Miocene of southern Germany.

The modern genus Citrus is now understood to include once more Fortunella Swin-

gle (kumquats) and Poncirus Raf. (trifoliate orange and therefore the sexual hybrids, $\times$ Citroncirus J. Ingram \& H.E. Moore and graft hybrids, + Citroponcirus $\mathrm{H}$. Wu et al. (Wu et al., 2004)), the genus being native throughout tropical South East Asia to subtemperate China to the north and Australia to the south (Mabberley, 1998; Pang et al., 2003; Bayer et al., 2004). Indeed it turns out (Mabberley, 1998) that Australia is the country with the highest number of indigenous Citrus species, some of which are now being brought into the trade as bush-tucker and are also being hybridized with existing crop plants (see below).

All Citrus have $2 \mathrm{n}=18$, though some cultivated forms have 27 and 36 , but there are no known wild polyploids (Frost, 1943). Hybrids are readily raised and, because seed can be set through apomixis, that is, without fertilization with embryos arising from the diploid nucellar tissue, desirable forms can readily be propagated. Antoni van Leeuwenhoek showed that such seeds often have several embryos, the first time the phenomenon of polyembryony in any plant was described (Palm, 1996: 219, t. 16). This is particularly common in the makrut or leech-lime, Citrus hystrix DC. and the calamondin, $C . \times$ microcarpa Bunge ('C.madurensis'; Lim, 2001). Hybridization and apomixis have led to the taxonomic havoc in the genus. 
The problem is that, despite an apparently large amount of work carried out on Citrus and its allies, the literature is in chaos. Much of this is due to the fact that the nomenclature used is not consistent because - quite simply - the basic taxonomic work has just not been done. There are good reasons for this. Workers have shied away from tackling a group for which almost all herbarium specimens are of cultivated plants, usually scrappy, with inadequate preservation of ripe fruits in alcohol - mature oranges and lemons do not make good herbarium specimens!

The problem is then pushed back to the fact that humans have been associated with these plants for a very long time and that, in bringing the species and selected forms of them together from outside their natural ranges, hybrids have arisen and by apomictic or other vegetative propagation certain lines have been fixed.

The most comprehensive account of the group (now well over 50 years old with minor revisions since) is Swingle's account in Webber \& Batchelor's 'The Citrus Industry' (1943). In it a lot of progress was made in that the hordes of apomictic clonal lines of cultivated plants were re-amalgamated in a smaller number of species, but the arrangement of them and the lack of understanding that all the commercial citrus are of complex hybrid ancestry (see Mabberley, 1997) means that the account is fatally flawed. More than this, several species we now know to be true Citrus were segregated in separate genera (Mabberley, 1998), so that when artificial hybrids were raised between such plants they were given unwieldy 'hybrid genera' names like $\times$ Citrofortunella J. Ingram $\&$ H.E. Moore and $\times$ Citroncirus (but many even worse).

Since that time the unravelling of the affinities within Citrus and between it and other Aurantioid genera has begun (Mabberley, 2002), but there is much to do (Morton et al., 2003; Bayer et al., 2004).

\section{PHYLOGENETICS}

Plastid DNA work (Samuel et al., 2001) has given us a preliminary phylogenetic tree which shows the Citrus group with Paramignya Wight as sister group. More distantly allied is Citropsis (Engl.) Swingle from tropical Africa, and again Swinglea Merr. and the Murraya L. - Merrillia Swingle complex, all from Asia. Even more distantly allied are the Asiatic Atalantia Corrêa and Pamburus Swingle. Other recent (published (e.g. Nicolosi et al., 2000; Morton et al., 2003; and Bayer et al., 2004 - the last based on three chloroplast regions) and unpublished) work has Paramignya not closely allied but puts African and Indian non-Citrus taxa in a group sister to Citrus in the broad sense (including Oxanthera Montrouz. and Clymenia Swingle) or to Citrus in the broad sense with an Asian Atalantia-Severinia clade.

This is just a (somewhat contradictory) start and, so far, a number of critical genera have not been included, e.g. the African Aeglopsis Swingle and the Asian Burkillanthus Swingle, Limonia L., Luvunga Wight \& Arn. (possibly congeneric with Paramignya) and Monanthocitrus Tanaka.

\section{CITRUS INFRAGENERIC RELATIONSHIPS}

As far as Citrus in the broad sense is concerned, Fig. 1. shows where we think we are, but there are somewhat contradictory molecular analyses including those of isozymes (Fang et al., 1994) and DNA work (De Araújo et al., 2003; Abkenar et al., 2004). 


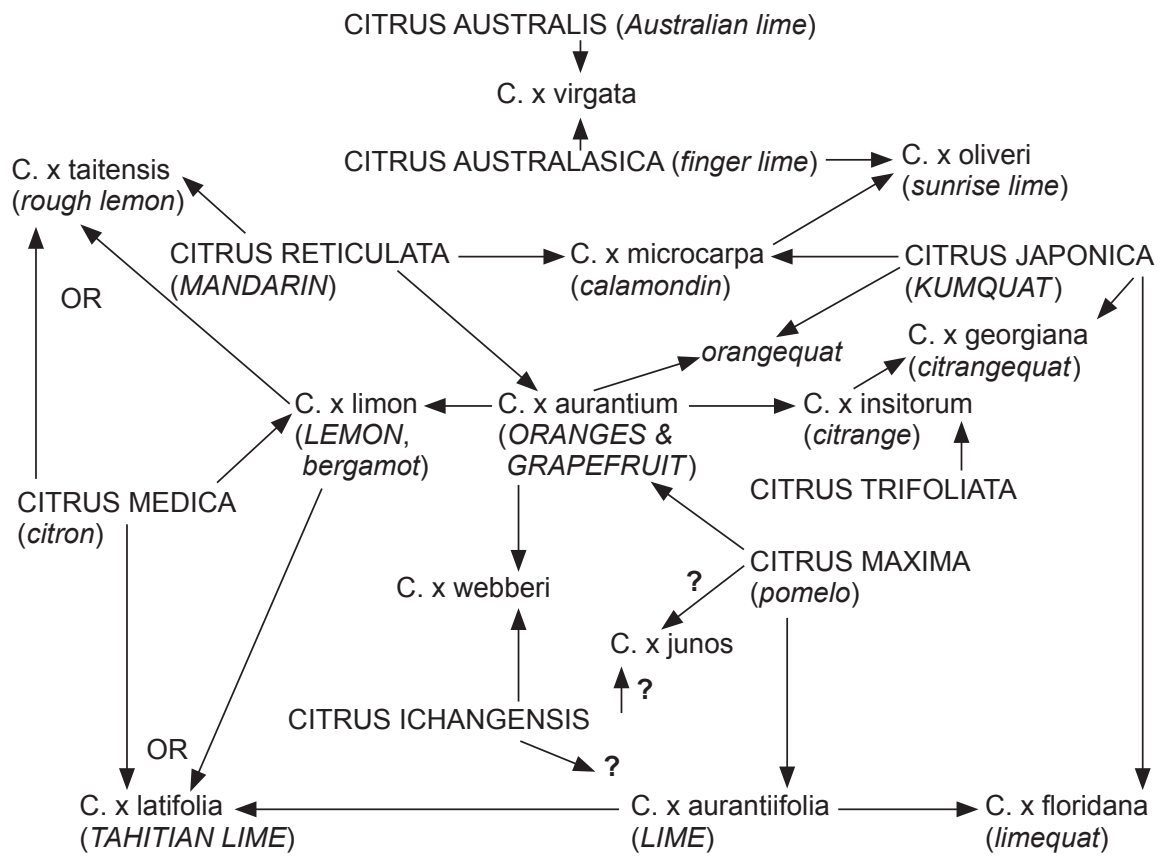

Fig. 1. The relationships of commercially significant citrus fruits and their wild allies, as revealed through hybridization and molecular analyses (modified from Mabberley, 2002). Names of parental, apparently truly, wild species are in roman block capitals, those of significant crop plants in italic block capitals.

This bewildering diagram represents the relationships of the commercial citrus crops and their wild allies and is the result of hybridization experiments besides DNA work. To understand how all this came about we need to have a feeling for the history of the peoples of South East Asia and the plants they collected, grew and exported. The records go back 2500 years, to Yu Gong, a writer in China.

Oranges and grapefruits derive from crosses (Citrus $\times$ aurantium L.) between the mandarin ( $C$. reticulata Blanco) and the pomelo (C.maxima (Burm.) Merr.), the first from China and the second perhaps from Indochina, their geographical isolation probably broken down by humans, such that when they met, spontaneous hybrids are likely to have formed, with apomictic clones being selected for propagation. The first cross is the sour orange now used in the West for marmalade, while the flower oil is the basis of eau de Cologne. Backcrosses with the parents gave the sour grapefruit (in the Caribbean in the eighteenth century) from C. maxima at one end, the sweet orange and tangelo from $C$. reticulata, at the other. These cultivars are grouped into cultivar groups under C. $\times$ aurantium, the sweet orange having been introduced to Europe in c. 1470 (Needham, 1986: 367). Interestingly the mandarin did not come in until the nineteenth century, though discussed in print in the eighteenth (see Osbeck, 1771 for example). 


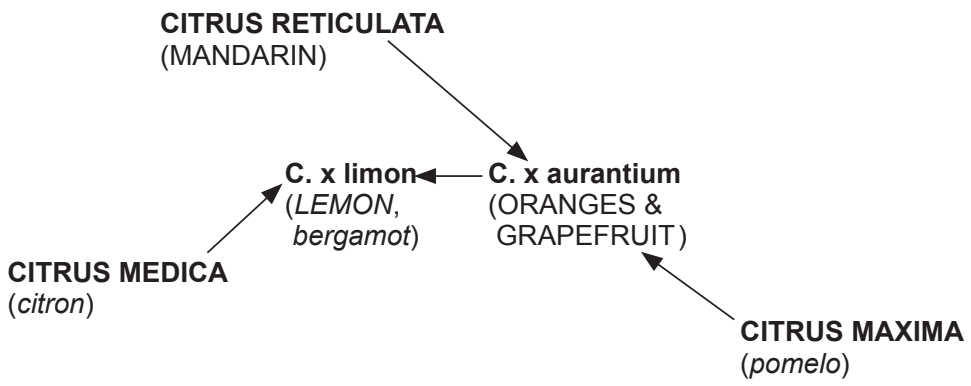

Fig. 2. The origins of oranges, grapefruit, lemons and bergamot.

Only after the synthesis of the bitter orange could lemons (laymūn in Arabic, but confusingly limon is the lime in French) have arisen, as they are crosses between oranges and the citron, a plant native in north-eastern India. DNA work, including that on both chloroplast and nuclear genes show that the lemon, $C . \times$ limon, has such an origin (Gulsen \& Roose, 2001). All crosses involving these two parents (from three original species), have to bear this name, so that the true bergamot, of which the rind oil is used in scent, hair oil, tanning oil and Earl Grey tea, apparently belongs here.

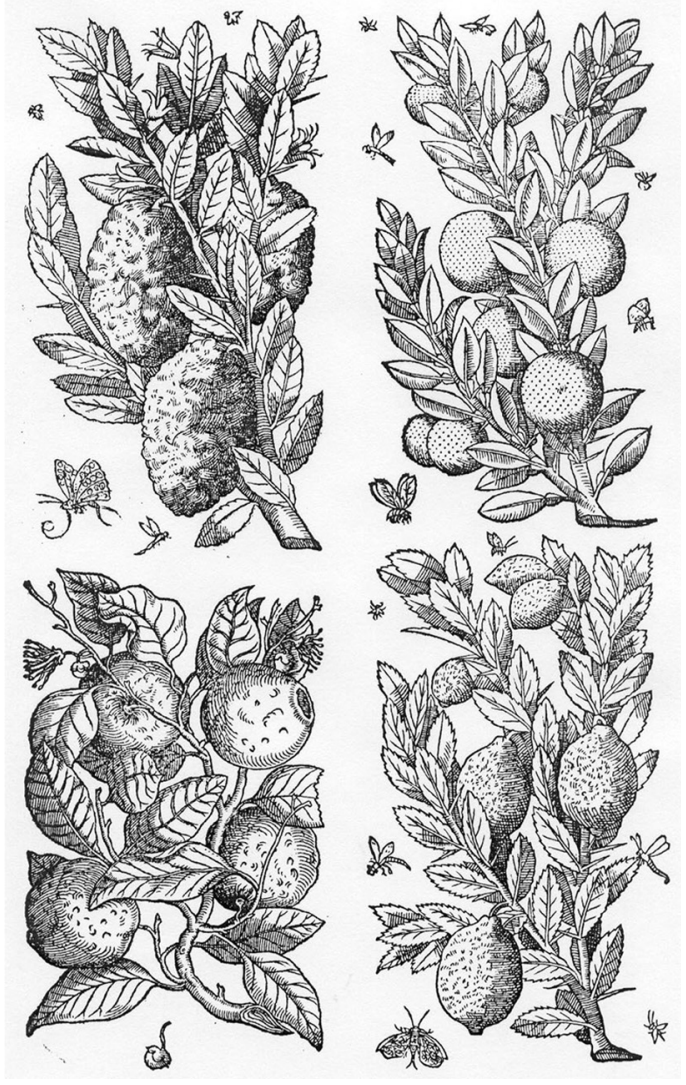

Fig. 3. Anonymous wood engravings from Jacques Dalechamps's 'Historia generalis plantarum' (1587). They are mirror images (plus insects) of engravings made for Mattioli's work (1559) (Ramón-Laca, 2003). Citron top left, sour orange top right, pomelo bottom left, lemon bottom right. 
These, the citron, orange, pomelo and lemon (Fig. 3), then, were the citrus fruits known in the West by the sixteenth century. Engravings of them were made for Andrea Mattioli's commentaries on Dioscorides' De materia medica, published in Venice in 1559 (Ramón-Laca, 2003).

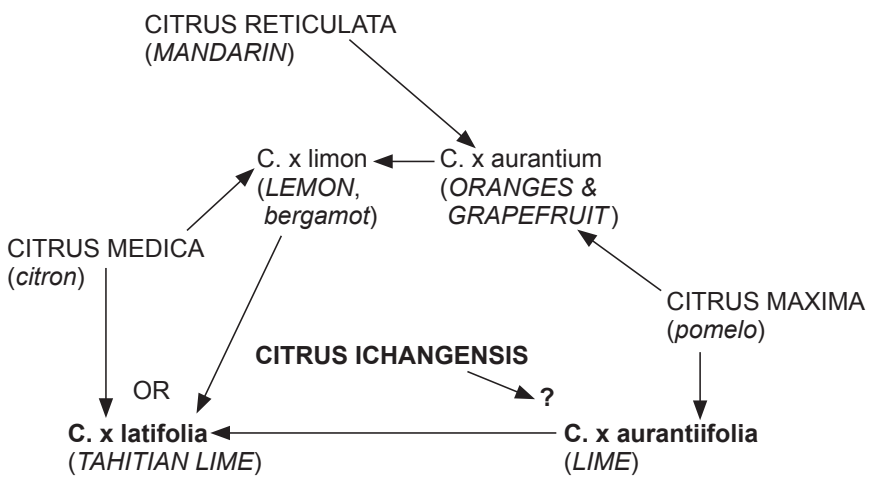

Fig. 4. The origins of the lime and the Tahitian lime.

The lime (līm in Arabic; confusingly limon in French, limoen in Dutch, but also ambiguous in English because lime is also used as the name for species of Tilia (Malvaceae)), Citrus $\times$ aurantiifolia (Christm.) Swingle, was the next known to the West and introduced thither, like most citrus, by the Muslim peoples (Ramón-Laca, 2003). One genome is from the pomelo, the other unknown, but perhaps from Citrus ichangensis Swingle, a plant said to be allied to $C$. hystrix DC. (Mabberley, 2002), the 'lime-leaves' of Thai cooking, a plant widespread in Malesia. The Tahitian lime, $C . \times$ latifolia (Yu. Tanaka) Tanaka, often seedless, is a backcross between lime, on the one hand, and citron or a lemon on the other. If the latter, it has genes from four wild species in its make-up.

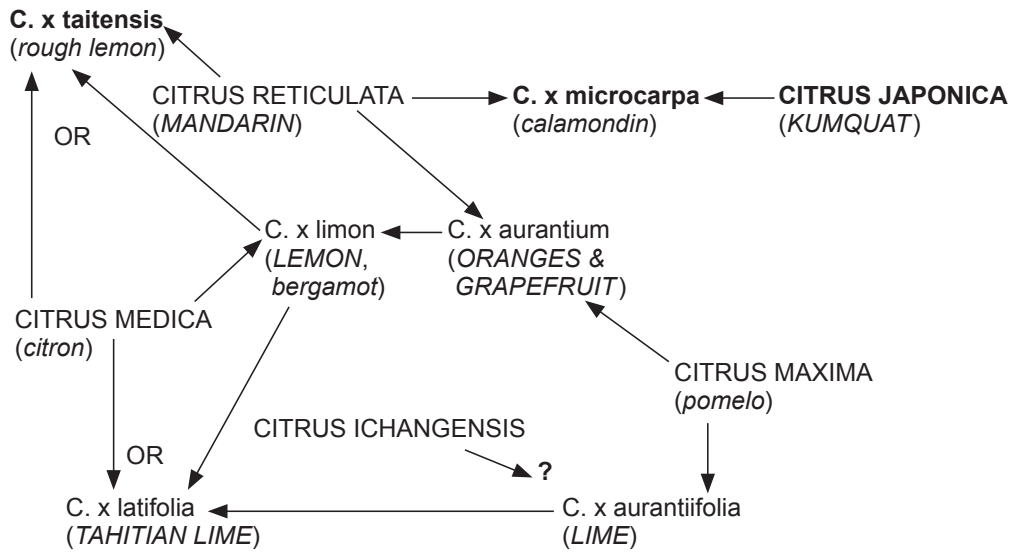

Fig. 5. The origins of the calamondin and the rough lemon.

The kumquat, Citrus japonica Thunb., grows further north than any of the citrus considered so far. Its fruit is eaten whole, often candied or in syrup. Crosses with the mandarin gave $C . \times$ microcarpa Bunge, the calamondin or calamansi, now very important 
in the Philippines, though where the cross was first made is unclear. Crosses between the mandarin and, according to Nicolosi et al. (2000), either the citron or lemon, apparently gave the rough lemon, $C . \times$ taitensis Risso. If involving the lemon, then it is just a backcross and rough lemons would have to be considered a cultivar group of lemons, so $C . \times$ taitensis would fall into the synonymy of $C . \times$ limon .

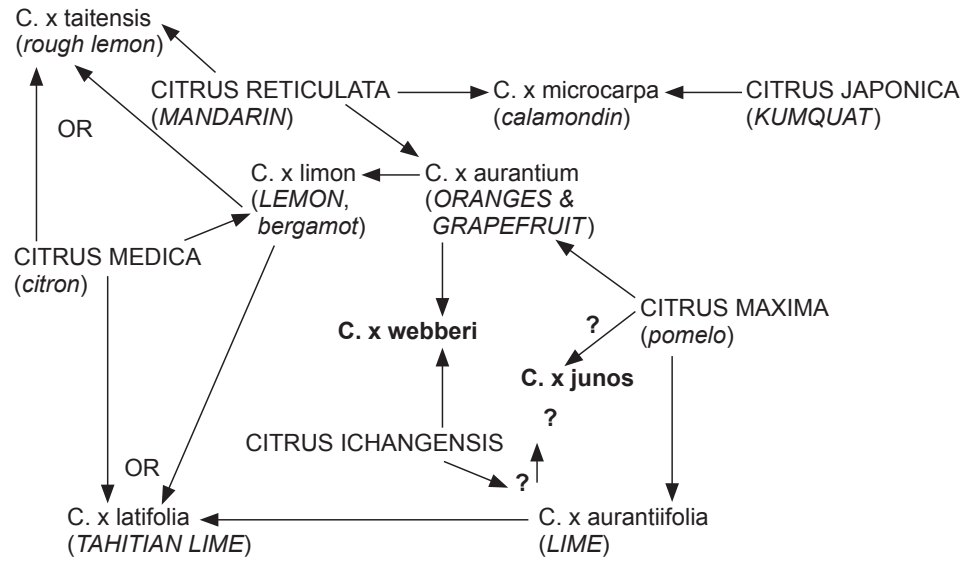

Fig. 6. The origins of other hybrids involving C.ichangensis.

Citrus ichangensis is not only a contender for a parent of the lime but was a parent, with $C . \times$ aurantium of $C . \times$ webberi Wester, raised in the Philippines in the twentieth century and, perhaps with $C$. maxima, long before, $C . \times$ junos Siebold ex Tanaka, a plant $(y u z u)$ discussed in Han Yen-Chih's 'Chü Lu' of c. 1178 AD.

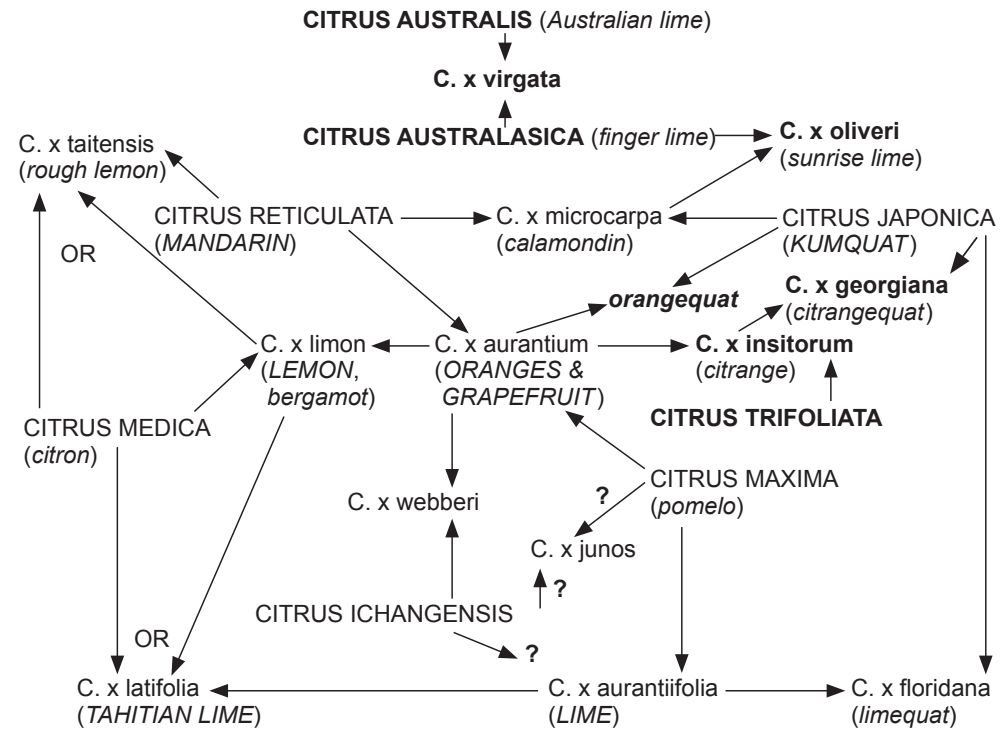

Fig. 7. The origins of certain modern interspecific hybrid citrus crops. 
Citrus trifoliata L. (Poncirus trifoliata (L.) Raf.) is a Chinese deciduous species with trifoliolate leaves, long used as a rootstock for oranges in China. It is hardy enough to be grown outside in northern Europe. Crossed with oranges, it gave $C . \times$ insitorum Mabb., the citrange, also a favoured rootstock. Crosses between the citrange and the kumquat first made by Walter Swingle at Eustis, Florida in 1909 gave Citrus $\times$ georgiana Mabb. ${ }^{2}$, the 'citrangequat' (Swingle \& Robinson, 1923; Webber, 1943: 665), a commercial crop (see e.g. Pijpers et al., 1986: 125) with several cultivars, two of Swingle's original hybrid crosses first fruiting in Georgia, USA. Some early hardy citrange cultivars, e.g. 'Troyer', are still used as rootstocks, but more recent ones, e.g. $C . \times$ insitorum ' 119 US', are now replacing the hardiest citrangequats like $C . \times$ georgiana 'Thomasville' (Bernhard Voss, pers. comm. 3 Sept. 2004) because of their superior orange-like fruits.

Crosses between oranges and kumquats are 'orangequats' of lesser importance (though many labelled thus are really $C$. reticulata $\times C$.japonica - Bernhard Voss, pers. comm. 3 Sept. 2004), those between limes and kumquats, 'limequats' $(C . \times$ floridana (J. Ingram \& H.E. Moore) Mabb.), these being more significant (Swingle \& Robinson, 1923).

The Australian $C$. australasica F. Muell., the finger lime, has been crossed with the allopatric C. australis (Mudie) Planch., the Australian lime, to give the 'Sydney Hybrid', C. $\times$ virgata Mabb. More importantly, commercial hybrids have recently been raised in Australia (Sykes, 2002) between C. australasica and Rangpur lime (perhaps a form of $C . \times$ limon) and also between $C$. australasica and calamondin, to give the 'blood lime' and 'sunrise lime', respectively. The latter hybrid was first made by George W. Oliver in the USA and has been called the 'faustrimedin' (Swingle, 1943: 360). It is here named to commemorate the pioneering hybridist: $C . \times$ oliveri Mabb. ${ }^{3}$

A number of other clear-cut species are not included here because in commerce there are no named interspecific hybrids involving them. They include $C$. glauca (Lindl.) Burkill from desert Australia, which is often weedy and its thorns a hazard to stock, besides four other native Australian species with two more in Papua New Guinea.

2) Citrus $\times$ georgiana, Mabb., hybr. nova

Hybrida hortensis, e Citrus japonica Thunb. et $C . \times$ insitorum Mabb. deorta, inter parentes media, sed foliis juvenilibus trifoliolatis, foliis ramulorum fructiferorum unifoliolatis, facile dignoscenda est.

Citrangequat. Type: $B$. Voss 2, Germany, 'Thomasville' citrangequat cultivated (from material received from Citrus Arboretum, Winterhaven, Florida, 1996; see http://members.aol.com/agrumivoss/ thomasv.jpg), at Voss's Töpferei und Citruspflanzen-Spezialgärtnerei, Moorende 149, Jork, September 2004 (holo L; iso NSW).

'Thomasville' is a cross between $C . \times$ insitorum 'Willits' (pollen parent) and the 'oval kumquat' made at Eustis, Florida in 1909. Fruits were first produced at Thomasville, Georgia, in 1915 (Webber, 1943: 665).

3) Citrus $\times$ oliveri Mabb., hybr. nova

Hybrida hortensis, e Citrus australasica F. Muell et $C . \times$ microcarpa Bunge deorta, inter parentes media, fructis foliisve $C$. australasica similibus, sed seminibus paucioribus, distincta est.

Faustrimedin. Type: B. Voss 3, Germany, cultivated (from material received in 1996 from Citrus Arboretum, Winterhaven, Florida, USA; see http://members .aol.com/agrumivoss/faust.jpg), at Voss's Töpferei und Citruspflanzen-Spezialgärtnerei, Moorende 149, Jork, September 2004 (holo L). 
Nonetheless, some selected forms of $C$. glauca are becoming of interest in Australia citrus growing. Citrus halimii Stone and C. swinglei Burkill ex Harms (perhaps a hybrid cf. Swingle, 1943: 349) are apparently truly wild citrus in Peninsular Malaysia, the first also recorded from Peninsular Thailand and Sabah (Borneo) but ? also Sumatra (fruiting material collected 1918/1919 from Simalur, Achmad 312,377, 997), while C. hystrix is apparently wild in much of central Malesia. Besides these species, a number of other cultivated citrus are yet to be incorporated in the scheme: these include sambal $(C$. amblycarpa Hassk.) and plants going under the names of $C . \times$ indica Tanaka (? hybrid involving C. ichangensis, cf. Swingle, 1943: 420-421), C. × macrophylla Wester, and 'C. $\times$ suhuiensis'.

What we need to know is of truly wild populations of citrus in Asia including Malaysia, Indonesia and the Philippines. We have a fair idea in Australia and New Guinea but, even there, there is much to be done. Even then, as far as I know, there are precious few observations on pollination in wild plants, only preliminary observations on germination, beyond those of Leeuwenhoek (e.g. Lim, 2001) and absolutely nothing on what the dispersal agents are or were (such big fruits as pomelos suggest primates, extinct large mammals or perhaps rhinoceros).

With this background, we can turn to the medicinal uses of these fruits.

\section{'FOLK' MEDICINE}

In his 'Enquiry into Plants', which in effect published the botanical findings of Alexander's Indian expedition, Theophrastus wrote of the 'Median', i.e. of the Medes, or 'Persian' apple, the citron, noting that it was not eaten but placed amongst clothes to deter moths. Indeed, we now know the peel does contain insecticidal limonoids. Theophrastus also discussed its use as a mouthwash and made the interesting biological observation that only flowers with a 'distaff', i.e. pistil, would yield fruits (Hort, 1916, I: 311,313), perhaps the first published observation on monoecy in any plant. The plant gained a reputation as an antidote to poison in classical times and the later Arab writers, notably Abu Marwan (d. 1162) in his 'Treatise of foodstuff', extolled its virtues in maintaining skin condition and as a tonic (Álvarez Arias \& Ramón-Laca, in press).

The naming of the citron as Citrus medica by Linnaeus perhaps indicates the early recognition of the pharmaceutical importance of the genus, though the epithet may refer to the Medes (see above), or, of course, to both. Virgil gave a poetic description of the fruit and its qualities and, in the time of Nero, the citron figured in the infamous banquet in the Satyricon of Petronius (Calabrese, 2002: 5). In the first century AD it was suggested as a remedy for gout and two centuries later a medical book prescribed citron syrup to stop a cough (Calabrese, 2002).

Han Yen-Chih's 'Chü Lu' (Orange Record) was printed in China in c. 1178 AD but it was largely pomological, whereas an almost contemporary Arabic monograph of lemons was mostly concerned with medicinal qualities (see Needham 1986: 377). By the Middle Ages in Europe peel of the rare and expensive sour orange was being recommended not merely as a flavouring but, when powdered and dissolved in wine, to prevent worms and the Black Death (Baldini, 1997: 96). By the end of the sixteenth century, forms of citron were included in the category of 'heart plants' through the Doctrine of Signatures and appear thus in Giambattista Porta's 'Phytognomica' published 


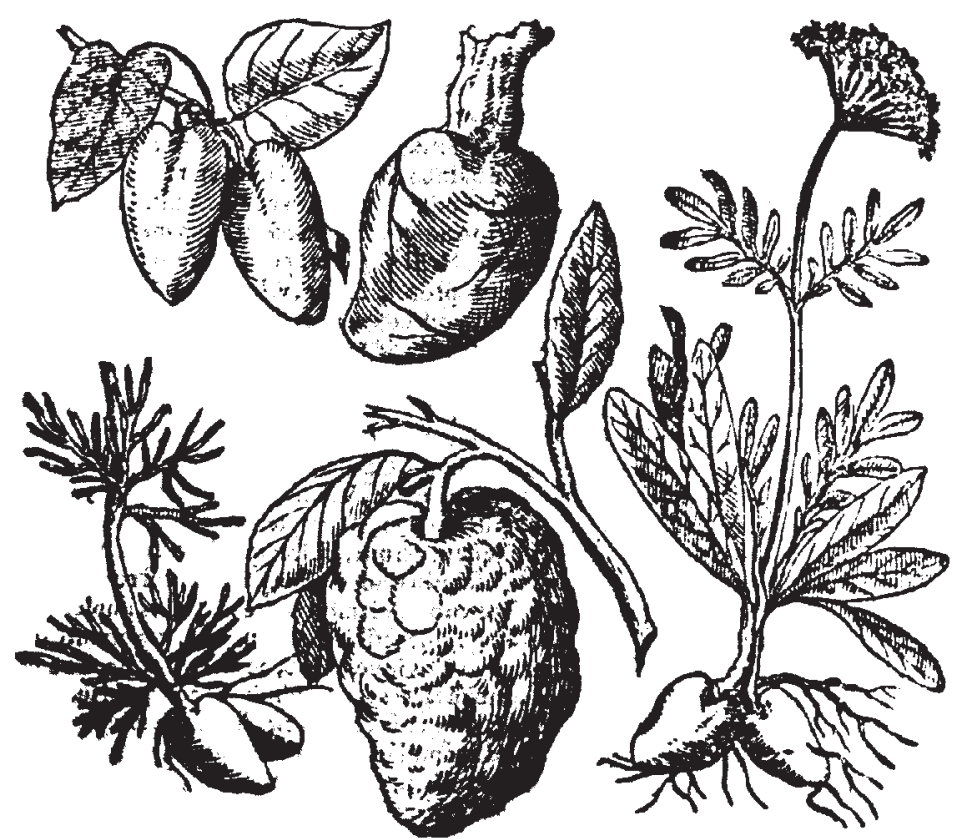

Fig. 8. Citron included in the category of 'heart plants' through the Doctrine of Signatures in Giambattista Porta's 'Phytognomica' (1588).

in Naples in 1588. From then on they figure conspicuously in European pharmacopeias (see Imbesi \& De Pasquale, 2002: 580 et seqq.).

From China (Valder, 1999: 247) to Indonesia, the citrus homelands, oranges and other citrus are still being used for an array of conditions from skin complaints like pimples to influenza and gout, and as febrifuges and vermifuges in Malaysia, where slices of lime dipped into flowers of sulphur are rubbed on the skin to treat fungal infections (Ong Hean Chooi, 1994). Salted fruits mashed in water are used as a remedy for coughs and sore throats and fresh juice is used to reduce blood pressure. To take a country far from the citrus homelands, Haiti, oranges are still used there to treat colds, fevers, liver and gall bladder problems, rheumatism and skin conditions. They are also used in voodoo magic and spells (Paul \& Cox, 1995).

\section{'WESTERN’ MEDICINE}

As early as 1948, it was realised that the antiseptic potency of citrus essential oils was greater than that of phenol (Bisignano \& Saija, 2002: 603). Some of the constituent compounds active against bacteria, fungi, protozoa and insects can be considered as phytoalexins, produced by the plant in response to attack. Limonene, different stereoisomers of which are responsible for the differing taste of orange and lemon juice, have different biological activities (Bisignano \& Saija, 2002: 603) and differences between citrus fruits in their efficacy may be at least partly due to this. It is interesting that the 
most efficacious tested was the citrange, $C . \times$ insitorum, a cross between $C$. trifoliata from northern China and an orange.

These compounds are part of the natural defences of the long-lived fruits, hanging on the trees for many months. They include citral, a mixture of two geometric isomeric aldehydes (Bisignano \& Saija, 2002: 607) and have been long-exploited. Even today a solution from boiled lemon peel is still a country remedy for acne in England (Vickery, 1995: 217), while in Australia native Citrus glauca is used in commercial skin cleansers. The makrut or leech lime, Citrus hystrix, is best known for its citronellal-rich leaves (Lawrence, 2002: 330) essential in cooking, but the hesperidium is still used to wash hair (as was noted in the seventeenth century by Rumphius) and, in Sri Lanka, to keep off leeches, apparently reflecting its insecticidal compounds having a rather broad range of effects on invertebrates.

\section{Scurvy}

The most famous example in the West was the alleviation of scurvy, the fatal disease caused by lack of vitamin $\mathrm{C}$ which is generally ingested from fresh fruit and vegetables: it used to kill more sailors than their human enemies did (Bown, 2003) and, until the nineteenth century, a 50\% fatality was common among sailing crews. The earliest record of using lemon juice to treat the disease is from the sixteenth century. When the East India Company sent its first ships to the east in 1601, the ship carrying lemon juice on board was the only one free of scurvy (Drummond \& Wilbraham, 1959: 139) and thereafter all EIC ships carried it, as did those of the VOC as early as the 1630s, though by the end of that century it had fallen out of favour in the face of the fashionable 'imbalance of bodily humours' type of medicine.

It was the controlled trial of James Lind (1716-1794), a surgeon, who identified citrus as a promising treatment in 1753, and Lieut. James Cook's use of citrus on his Pacific voyages that led physicians to impress its importance on the British Admiralty. From 1795, the Admiralty issued sailors with daily draughts of lemon juice, usually added to their rum ration (Drummond \& Wilbraham, 1959: 391-392). The improved health of the British navy gave Nelson a strategic advantage over Napoleon's fleet at the Battle of Trafalgar (1805).

In the mid-nineteenth century, lime-juice from the West Indies was substituted for lemon-juice from the Mediterranean, hence the Americans' calling British sailors 'limeys' or 'limers', but lime-juice has less vitamin C than do either lemons or oranges and is therefore less effective than they are in preventing the disease. No doubt this reflects its parentage, which includes neither the mandarin which is in the parentage of both lemon and orange, nor the citron, another of the lemon's ancestors. In the Crimean War, the French army ate many vegetables, the British less so, scurvy causing more deaths than any other single cause: the fact that lime-juice had been sent out in 1854 but was never used was one of the scandals raised by no less a critic than Florence Nightingale in her evidence on the conduct of the war (Drummond \& Wilbraham, 1959: 396).

At the end of World War II, there was an enormous effort to boost orange-juice consumption by children in Europe. Vitamin $\mathrm{C}$ is still one of the most popular dietary supplements on the market, often starting at $250 \mathrm{mg}$ per day, when 75 for women and 90 for men is the recommended allowance. Its use in treatment of colds has probably been vastly over-rated, largely because of the prominence of Linus Pauling's 'Vitamin C 
and the common cold' (1970). It is, however, an antioxidant and promotes collagen production, apparently also promoting vasodilation and reducing risk of heart attack in patients with high cholesterol and hardening of arteries. The hesperidium contains vitamin C, but less than many other fruits, but citrus's natural packaging is superior. In the wild is this vitamin source a reward for dispersal agents or for what? Only primates (and guinea-pigs) are unable to synthesize it.

\section{Weight loss}

Perhaps a more pressing matter in today's western world is rising obesity and the never-ending obsession with diet. Early last century some clinicians claimed that lemon juice countered obesity (Imbesi \& De Pasquale, 2002: 588) and in the 1970s there was a fad for the Grapefruit Diet, particularly in North American women. Very recent re-examination of the action of grapefruit, a mandarin-pomelo cross, has shown that the fruit's 'membrane' has a 'compound' that interacts in the liver to lower cholesterol and help regulate insulin. The identity of the efficacious 'compound' is unclear (Ken Fujioka of the Scripps Clinic, San Diego, quoted on www.wral.com/health/2262919/ detail.html, accessed 2 February 2004).

Nonetheless, a three-month study has shown that adults who ate half a grapefruit with each regular meal (three times a day) lost $1.6 \mathrm{~kg}$ on average compared with those on an otherwise identical diet who lost $0.2 \mathrm{~kg}$, some losing as much as $4.5 \mathrm{~kg}$; juice alone had a measurable effect too. The study involved 1000 obese adults who, by the end of the experiment, were found also to have reduced levels of insulin and glucose.

\section{Contraception}

In the 1890s it was reported that negro women in tropical America used a douche solution of lemon juice 'mixed with a decoction of the husks of mahogany nut' as a contraceptive and it has long been known that an aqueous solution of lemon juice is an effective spermicide, Casanova (Giovanni Jacopo Casanova de Seingalt, 1725-1798) reporting it in the eighteenth century (Himes, 1936: 17-18). Casanova also noted that lemons could be used to detect venereal infection in women, because if the labia are raw through infection, they would smart on application of the juice (Himes, 1936: 181). He also considered that a small lemon from which the juice had been extracted might make an efficacious cervical cap.

Women in eighteenth-century Istanbul inserted a sponge moistened with dilute lemon juice after coitus and in the 1930s Himes (1936: 182, 185) considered this unsurpassed by "any modern clinical contraceptive". Right up today, prostitutes in Lahore, Pakistan, Jos and Kano, Nigeria, as well as in Laos, use this technique (R. Short, pers. comm. 5 Nov. 2004). Recent experimental work has shown that "a $20 \%$ final concentration of lemon juice in fresh human ejaculate irreversibly immobilises $100 \%$ of sperm in under 30 seconds" (Short et al., 2004). The citric acid destroys proteins of the mitochondria, thereby causing immobility (R. Short, pers. comm. 6 Feb. 2004).

\section{LemonAIDS}

Currently experiments are being undertaken in the Australian LemonAIDS programme (www.aids.net.au/lemons-lemonaids.htm) to ascertain whether lemon juice is able to prevent cellular infection with HIV-1. At concentrations of 5\% and above, 
infection seems to be inhibited. A $50 \%$ solution $(\mathrm{pH} 2.7)$ neutralized all virus within two minutes. It is concluded that the citric acid causes surface proteins in the envelope of the virus to be altered such that no binding and subsequent infection can occur (R. Short, pers. comm. 6 Feb. 2004).

Lemon-juice, again perhaps reflecting the lemon's ancestry is more efficacious than lime-juice, though both are better than commercially available microbicides. Experiments with macaques have shown that its use as a vaginal microbicide is safe in primates and clinical trials are now under way in Thailand. It is estimated that a microbicide with only $40 \%$ efficacy against HIV transmission, at $30 \%$ coverage of the sexually active population, would avert more than 5.6 M HIV infections per annum; at even only $20 \%$ coverage $4 \mathrm{M}$ would be. It is interesting to note that human ejaculate already contains citric acid, so that new applications may be merely reinforcing a natural microbicide (Short et al., 2004).

The significance of these findings in a folk medicine for the control of population and the spread of HIV are obvious. And, besides the insecticides and fungicides, there is more (see also Álvarez Arias \& Ramón-Laca, in press). Flavonoids, particularly flavonones from the hesperidia have been intensively studied for antioxidant, anticancer (e.g. breast cancer - Tian et al.,2001), antiviral and anti-inflammatory activities, effects on capillary fragility and an observed inhibition of human platelet aggregation. Commercially valuable flavonoid-based industrial products are the anti-sweetening agents, hesperidin and naringin and their byproducts (Licandro \& Olio, 2002: 170) - used in some tonic water for example. And, again, fruits of one form of Citrus hystrix are hung on hooks in the self-mortification of the back by devotees in the Hindu festival of Thaipusam; whether it is the white ash or milk often used at the same time or compounds from the fruits that help to numb the skin is still unclear, though sometimes at least the fruits alone are used, suggesting they themselves may contain an effective anaesthetic agent.

\section{CONSERVATION}

We do not know where the commercial citrus hybridizations were first accidentally made. It is likely that the forests where the parental species grew have been lost or greatly modified. We are dealing today largely with clones in cultivation and it is not clear where wild populations of their parental species survive. Because of this, little can be said about the in situ conservation of genetic resources for these most important plants. Suffice it to say that as far as I know there is only one species being protected anywhere and that is in the Northern Territory of Australia (Fig. 9): paradoxically, it is the last-described species, Citrus gracilis Mabb. (Mabberley, 1998). Clearly we have a great deal to do!

\section{ACKNOWLEDGEMENTS}

I am grateful to Bernhard Voss (Jork, Germany) for supplying modern hybrid citrus material from his nursery, to Johan Mols (Leiden) for help with the illustrations, to Luis Ramón-Laca (Madrid) and Hanneke Wilson (Oxford) for advice on etymological matters, and especially to Professor Roger Short (Melbourne) for sharing recent advances in the LemonAIDS programme. 


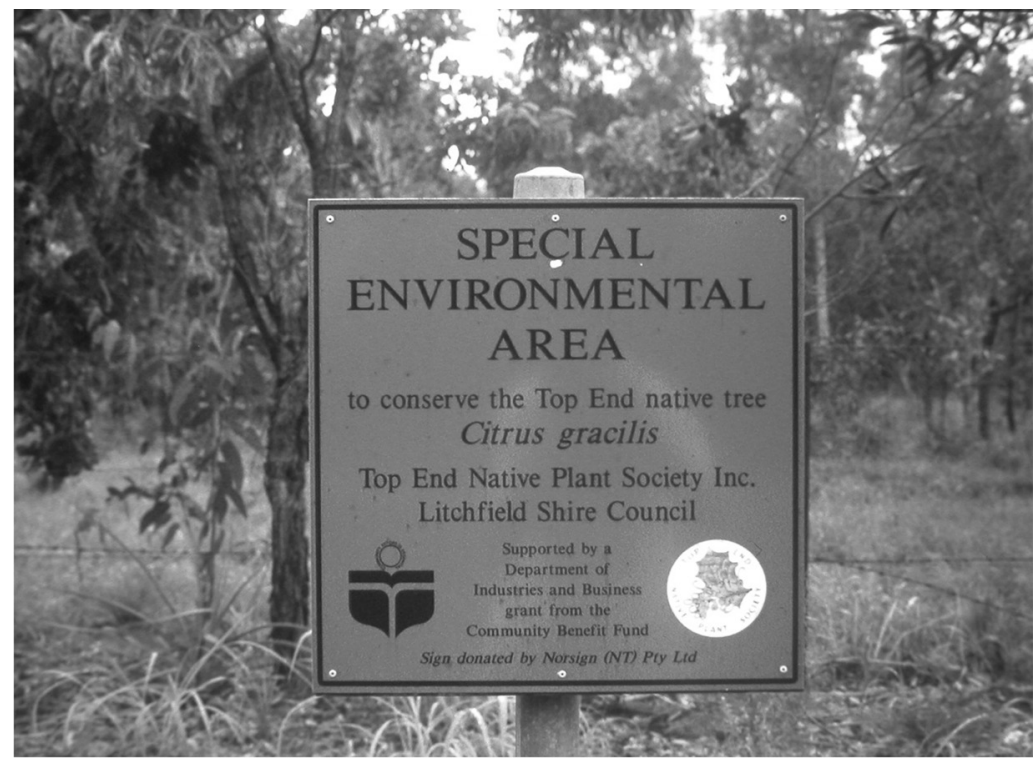

Fig. 9. Citrus gracilis reserve near Darwin, Northern Territory, Australia (photo D.J. Mabberley).

\section{REFERENCES}

Abkenar, A.A., S. Isshiki \& Y. Tashiro. 2004. Phylogenetic relationships in the "true citrus fruit trees" revealed by PCR-RFLP analysis of cpDNA. Scient. Hort. 102: 233-242.

Álvarez Arias, B. \& L. Ramón-Laca. In press. Pharmacological properties of citrus fruits and their ancient and medieval uses in the Mediterranean region. J. Ethnopharmacol.

Baldini, E. 1997. The role of Cassiano dal Pozzo's Paper Museum in citrus taxonomy. In: D. Freedberg \& E. Baldini, The Paper Museum of Cassiano dal Pozzo. Series B - part one. Citrus Fruits: 85-99. Miller, London.

Bayer, R., S. Rich, C. Morton, D.J. Mabberley \& S. Sykes. 2004. Phylogenetic relationships of the Australasian Citrus (Rutaceae: Aurantioideae). Abstracts, Botany 2004, Snowbird, Utah, August 2004: 105.

Bisignano, G. \& A. Saija. 2002. The biological activity of citrus oils. In: G. Dugo \& A. Di Giacomo (eds.), Citrus. The genus Citrus: 602-630. Taylor \& Francis, London \& New York.

Bown, S.R. 2003. Scurvy: how a surgeon, a mariner, and a gentleman solved the greatest medical mystery of the age of sail. Allen, Toronto.

Calabrese, F. 2002. Origin and history. In: G. Dugo \& A. Di Giacomo (eds.), Citrus. The genus Citrus: $1-15$. Taylor \& Francis, London \& New York.

De Araújo, E.F., L.P. de Queiroz \& M.A. Machado. 2003. What is Citrus - taxonomic implications from a study of cp-DNA evolution in the tribe Citreae (Rutaceae-Aurantiodeae). Org. Divers. Evol. 3: 55-62.

Drummond, J.C. \& A. Wilbraham. 1959. The Englishman's food. A history of the customs of English diet. Revised ed., Readers Union \& Cape, London.

Fang, D-Q., W-C. Zhang \& S.Y. Xiao. 1994. Isozymes and classification of Citrus species in China [English abstract]. Acta Bot. Sin. 36, suppl.: 124-138.

Fernández, F. \& L. Ramón-Laca. 2002. El tratado sobre los citricos de Nicolás Monardes. Asclepio 54: 149-164 [not seen]. 
Fisher, T.C. \& R. Butzmann. 1998. Citrus melitensis (Rutaceae), a new species from the Pliocene of Valdarno (Italy). Pl. Syst. Evol. 210: 51-55.

Frost, H.B. 1943. Genetics and breeding. In: H.J. Webber \& L.D. Batchelor (eds.), The citrus industry I. History, botany, and breeding: 817-913. University of California Press, Berkeley \& Los Angeles, USA.

García Guijarro, L. 1957. Hespérides o la rigueza citricola española. Madrid [quoted in Ramón-Laca 2003].

Glare, P.G.W. (ed.). 1982. Oxford Latin Dictionary. Oxford University Press, Oxford.

Goody, J. 1993. The culture of flowers. Cambridge University Press, Cambridge.

Gulsen, O. \& M.L. Roose. 2001. Chloroplast and nuclear genome analysis of the parentage of lemons. J. Amer. Soc. Hort. Sci. 126: 210-215.

Hammond, N.G.L. \& H.H. Scullard. 1970. The Oxford Classical Dictionary. Ed. 2. Clarendon Press, Oxford.

Himes, N.E. 1936. Medical history of contraception. Williams \& Wilkins, Baltimore.

Hort, A. [Theophrastus]. 1916. Enquiry into plants and minor works on odours and weather signs. 2 vols. Harvard University Press, Cambridge (Mass.) \& Heinemann, London.

Imbesi, A. \& A. De Pasquale. 2002. Citrus species and their essential oils in traditional medicine. In: G. Dugo \& A. Di Giacomo (eds.), Citrus. The genus Citrus: 577-601. Taylor \& Francis, New York.

Jackson, B.D. 1900. A glossary of botanic terms. Duckworth, London.

Lawrence, B.M. 2002. The oil composition of less common Citrus species. In: G. Dugo \& A. Di Giacomo (eds.), Citrus. The genus Citrus: 318-354. Taylor \& Francis, London \& New York.

Licandro, G. \& C.E. Olio. 2002. Citrus by-products. In: G. Dugo \& A. Di Giacomo (eds.), Citrus. The genus Citrus: 159-178. Taylor \& Francis, London \& New York.

Lim, A.K. 2001. Citrus and citroids: recent biological findings. Malayan Nat. J. 55: 221-229.

Lippi, M.M. 2000. The garden of the 'Casa delle Nozze di Ercoli ed Ebe' in Pompeii (Italy): palynological investigations. Plant Biosystems 134: 205-211.

Mabberley, D.J. 1997. A classification for edible Citrus. Telopea 7: 167-172.

Mabberley, D.J. 1998. Australian Citreae with notes on other Aurantioideae (Rutaceae). Telopea 7: 333-344.

Mabberley, D.J. 2002. Limau Hantu and Limau Purut: the story of lime-leaves (Citrus hystrix DC., Rutaceae)? Gard. Bull. Singapore 54: 185-197.

Mabberley, D.J. 2004. European discovery, description and naming. In: V. Sripathy (ed.), Red Cedar in Australia: 22-41, 108-110. Historic Houses Trust of New South Wales, Sydney.

Manniche, L. 1989. An ancient Egyptian herbal. British Museum, London.

Meiggs, R. 1982. Trees and timber in the Ancient Mediterranean World. Clarendon, Oxford.

Morton, C.M., M. Grant \& S. Blackmore. 2003. Phylogenetic relationships of the Aurantioideae inferred from chloroplast DNA sequence data. Amer. J. Bot. 90: 1463-1469.

Needham, J. 1986. Science and civilisation in China 6, 1. Botany. Cambridge University Press, Cambridge.

Nicolosi, E., Z.N. Deng, A. Gentile, S. La Malfa, G. Ciontinella \& E. Tribulato. 2000. Citrus phylogeny and genetic origin of important species as investigated by molecular markers. Theor. Appl. Genet. 100: 1155-1166.

Ong Hean Chooi. 1994. The ethnobotnay [sic] of Citrus and their relatives. Korean J. Pl. Taxon. 24: 157-171.

Osbeck, P. 1771. A voyage to China and the East Indies 1. Translated into English by J.R. Forster. White, London.

Palm, L.C. (ed.). 1996. Alle brieven van Antoni van Leeuwenhoek. Vol. 14. Swets \& Zeitlinger, Lisse.

Pang, X-M., C-G. Hu \& X-X. Deng. 2003. Phylogenetic relationships among Citrus and its relatives as revealed by SSR markers. Acta Genet. Sin. 30: 81-87.

Paul, A. \& P.A. Cox. 1995. An ethnobotanical survey of the uses of Citrus aurantium (Rutaceae) in Haiti. Econ. Bot. 49: 249-256.

Pijpers, D., J.G. Constant \& K. Jansen. 1986. The complete book of fruit. Admiral Books, London. 
Ramón-Laca, L. 2003. The introduction of cultivated citrus to Europe via northern Africa and the Iberian Peninsula. Econ. Bot. 57: 502-514.

Samuel, R., F. Ehrendorfer, M.W. Chase \& H. Greger. 2001. Phylogenetic analyses of Aurantioideae (Rutaceae) based on non-coding plastid DNA sequences and phytochemical features. Pl. Biol. 3: 77-87.

Short, R.V., S.G. McCoombe, C. Maslin, E. Naim \& S. Crowe. 2004. Lemon and lime juice as potent natural microbicides. Abstracts of papers for World AIDS Conference Bangkok 8-16 July 2004.

Swingle, W.T. 1943. The botany of citrus and its wild relatives of the orange subfamily (family Rutaceae, subfamily Aurantoideae). In: H.J. Webber \& L.D. Batchelor (eds.), The citrus industry I. History, botany, and breeding: 129-474. University of California Press, Berkeley \& Los Angeles, USA.

Swingle, W.T. \& T.R. Robinson. 1923. Two important new citrous hybrids for the home garden, citrangequats and limequats. J. Agric. Res. 23: 229-238.

Sykes, S.R. 2002. Citrus hybrid. Hybrid finger lime. Pl. Var. J. 15, 4: 19-21.

Tian, Q., E.G. Miller, H. Ahmad, L. Tang \& B.S. Patil. 2001. Differential inhibition of human cancer cell proliferation by citrus limonoids. Nutrition and Cancer 40: 180-184 [not seen].

Valder, P. 1999. The garden plants of China. Florilegium, Balmain, NSW.

Vickery, R. 1995. A dictionary of plant lore. Oxford University Press, Oxford.

Webber, H.J. 1943. Cultivated varieties of citrus. In: H.J. Webber \& L.D. Batchelor (eds.), The citrus industry I. History, botany, and breeding: 475-668. University of California Press, Berkeley \& Los Angeles, USA.

Wu, H., B-m Lin, Z-x. Lai, L-x Lü, G-f. Lin, D-m. Pan \& J-f. Yang. 2004. An intergeneric grafting chimera name: Citroponcirus ‘Hormish'. J. Trop. Subtrop. Bot. 12: 177-181. 